СД-44.

\title{
ИСПОЛЬЗОВАНИЕ МЕТОДА ФИЗИКО-ХИМИЧЕСКОГО МОДЕЛИРОВАНИЯ ПРИ ОПРЕДЕЛЕНИИ ФАЗОВОГО СОСТАВА ЖЕЛЕЗНЫХ РУД
}

Чубаров В.М. ${ }^{1}$, Ощепкова А.В. ${ }^{1,2}$, Кондратьева Е.М. ${ }^{2}$, Белозерова О.Ю. ${ }^{1}$, Канева Е.В. ${ }^{1}$

${ }^{1}$ ФБГУН Институт геохимии им. А.П. Виноградова СО РАН, Иркутск, Россия

${ }^{2}$ ФГБОУ ВО Иркутский государственный университет, Иркутск, Россия

$$
\text { chubarov@igc.irk.ru }
$$

DOI: 10.26902/ASFE-11_137

Железные руды представляют собой сложные минеральные системы, содержащие помимо минералов железа также силикаты, карбонаты и оксиды других элементов. Оценка промышленной значимости железорудных месторождений требует не только точного определения химического состава руд, но и соотношения минеральных фаз, входящих в их состав. Идентификация фазового состава руд методом порошковой рентгеновской дифракции часто возможна только качественно. Метод рентгеноспектрального электронно-зондового микроанализа (РСМА) дает точную информацию о химическом и фазовом составе, но количественная оценка соотношения минеральных фаз этим методом затруднительна, так как требует достаточно длительной процедуры сканирования больших размеров поверхностей образцов.

Предложен альтернативный способ определения фазового состава при помощи физикохимического моделирования, позволяющего по химическому составу качественно и количественно оценить соотношение минеральных фаз. Метод основан на минимизации свободной энергии Гиббса и реализован в программном комплексе «Селектор» [1]. В решении модели рассматривается гетерогенная мультисистема из зависимых компонентов (минеральных фаз), смоделированных на основе данных о химическом составе. В модели также рассчитываются обобщенные стехиометрические формулы минералов с переменным составом (полевые шпаты, слоистые алюмосиликаты), что позволяет повысить точность расчета [2, 3]. Результаты количественного определения фазового состава стандартных образцов железных руд были сопоставлены с результатами рентгенофазового анализа на дифрактометре D8 Advance (Bruker AXS, Германия), PCMA на рентгеноспектральном микроанализаторе Superprobe JXA-8200 (JEOL Ltd, Япония) и данными сертификатов. Все используемые методы идентифицируют основные рудные компоненты, однако метод физикохимического моделирования позволяет дополнительно получить сведения о минеральном составе вмещающей породы и не только предсказать основные минеральные фазы, но и установить их количество Расчетные содержания силикатных минералов в ряде случаев расходятся с аналитически определенными, поскольку моделирование нацелено на оценку железорудных минералов и модели твердых растворов алюмосиликатов идеализированы. В дальнейшем точность расчета может быть повышена использованием дополнительных данных о минеральном составе.

\section{Список литературы}

1. Чудненко К.В. Термодинамическое моделирование в геохимии: теория, алгоритмы, программное обеспечение, приложения. Новосибирск: Академическое издательство «Гео», 2010. 287 с.

2. Ощепкова А.В., Кузьмин М.И., Бычинский В.А., Солотчина Э.П., Чудненко К.В. Модели твердых растворов для расчета минерального состава донных осадков озера Байкал: новый подход к палеоклиматическим реконструкциям // Доклады АН. 2015. Т. 461. № 4. С. 447.

3. Смелый Р.В., Канева Е.В., Ощепкова А.В., Бычинский В.А., Айсуева Т.С., Щетников А.А., Пашкова Г.В., Якимов И.С., Финкельштейн А.Л. Определение минерального состава озерных донных отложений методами рентгеновской дифракции и физико-химического моделирования // Журнал СФУ. Химия. 2019. Т. 12. № 3. С. 382.

Исследование проведено в рамках выполнения государственного задания по Проекту № 0284-2021-0005 при финансовой поддержке РФФИ (грант 18-33-20104) с использованием оборудования Центра коллективного пользования «Изотопно-геохимических исследований» ИГХ СО РАН. 